\title{
Correspondence
}

\section{National DNA Database and psychiatric patients}

The advent of DNA analysis as a powerful tool for crime detection has led to the creation of England and Wales's National DNA Database (NDNAD). This is one of the world's largest databases of DNA information, storing profiles of nearly 5 million individuals. ${ }^{1}$ We write to raise a concern about the potential impact of this database on people with mental disorders.

The NDNAD has long been the subject of scrutiny and criticism with regard to how DNA profiles are collected and retained and from whom. This is because the current regulations on DNA profile collection mean that the NDNAD includes DNA profiles of a large number of people who have never been convicted of any crime. These DNA profiles are currently retained indefinitely. This practice was challenged in the European Court of Human Rights who found England and Wales to be in breach of the European Convention on Human Rights. In light of this, both the current and previous UK governments have signalled their intention to enact reform but as yet there has been no change in legislation.

Some groups, including young Black men, are known to be overrepresented on the database ${ }^{2}$ and we are concerned that those with mental health problems, a vulnerable group of people, are similarly affected. This issue has been largely unexamined and there are no estimates for the number of people with mental disorders on the NDNAD. However, in $2008,9 \%$ of mental health in-patients were admitted via the criminal justice system. ${ }^{3}$ Furthermore, studies of individuals in prison and on remand have concluded that mental disorder is extremely common in these populations, with respective rates of $90 \%$ and $63 \%{ }^{4,5}$ It would be surprising if the population of those on the NDNAD were not to broadly reflect this state of affairs.

It is arguable that a person with mental health problems who has a profile on the NDNAD despite being without criminal conviction is not only disadvantaged but also criminalised. This is a potentially unhelpful outcome for the process of engagement and recovery. We have concerns about how some patients come to be on this database. Patients arrested as a direct result of their mental state may find themselves on the database despite being diverted into mental health services without charge. Given that police powers allow that reasonable force may be used to take a DNA sample without consent, a disturbed and oppositional patient may be injured in the process. There is also lack of any formal pathway for removal from the NDNAD, which is at present difficult to navigate.

The new UK coalition government has undertaken to adopt the current Scottish model whereby DNA profiles of those arrested but not convicted are retained for 6 years only. DNA profiles of those convicted will be kept indefinitely as before. This reform would go some way to addressing our concerns.

We would welcome a debate among clinicians on the issues surrounding mental health patients and the National DNA Database.
Declaration of interest

Both authors are members of campaign groups Liberty and No2id. Neither of these organisations was involved with this letter at any stage.

1 National Police Improvement Agency. National DNA Database: Annual Report 2007-09. NPIA, 2009 (http://www.npia.police.uk/en/docs/ NDNAD07-09-LR.pdf).

2 Rt Hon Baroness Scotland of Asthal QC, Minister for Criminal Justice and Offender Management. Minutes of Evidence 13 March 2007 (Q653). House of Commons, 2007 (http://www.publications.parliament.uk/pa/ cm200607/cmselect/cmhaff/181/7031305.htm).

3 Commission for Healthcare Audit and Inspection. Count Me In 2008: Results of the 2008 National Census of Inpatients in Mental Health and Learning Disability services in England and Wales. Commission for Healthcare Audit and Inspection, 2008. (http://www.cqc.org.uk/_db/ _documents/Count_me_in_census_2008_Results_of_the_national_ census_of_inpatients_in_mental_health_and_learning_disability_ services.pdf).

4 Singleton N, Meltzer H, Gatward R. Psychiatric Morbidity among Prisoners in England and Wales (Office for National Statistics). TSO (The Stationery Office), 1998.

5 Maden A, Taylor CJA, Brooke D, Gunn J. Mental Disorder in Remand Prisoners. Home Office, 1995.

Stephen Ginn ST4 General Adult Psychiatry, East London NHS Foundation Trust, Tower Hamlets Home Treatment Team, Mile End Hospital, London, email: stephen.ginn@eastlondon.nhs.uk, Lisa Conlan ST5 General Adult Psychiatry, South London and the Maudsley NHS Trust, London.

doi: 10.1192/pb.34.11.496

\section{Not with a bark}

It was a great relief to read Professor Burns' editorial ${ }^{1}$ concerning the loud silence around the separation of in-patient and out-patient consultant care. The dogs have certainly not barked, not even growled.

This is the largest single change in clinical practice in my working life and appears to go against the grain of other developments. There is no evidence base for it, nor could it be described as patient-centred. The past two decades of enquiries have often pointed to discontinuity of care and communication problems as potential risks, and both are likely consequences of 'functionalisation'. There may well be positive outcomes with regard to in-patient care, but I believe these could have been achieved without reducing the quality of community care.

Consultants are an expensive resource and I wonder whether the future will see reduced numbers of senior medical professionals working mainly as psychopharmacologists with in-patients, whereas the community service is provided by other disciplines alongside primary care. Is this the way psychiatry ends, not with a bark but a whimper?

1 Burns T. The dog that failed to bark. Psychiatrist 2010; 34: 361-3.

Gary S. Hosty Community Psychiatrist, Telford, UK, email: hosty@tinyworld.co.uk

doi: $10.1192 / p b .34 .11 .496 a$ 